\title{
The Blend of Normative Uncertainty and Commercial Immaturity in Swedish Ice Hockey
}

\author{
Re-submitted for publication in Sport in Society (February 2014).
}

By describing and analysing normative uncertainties and the commercial immaturity in Swedish ice hockey (SHL/SIHA), this article focuses on the tension and dialectics in Swedish sport; increasingly greater commercial attempts (i.e., entrepreneurship, 'Americanisation', multi-arenas, innovations and public limited companies (plcs)) have to be mixed with a generally non-profit making organisation (e.g., the Swedish Sports Confederation) and its traditional values of health, democracy and youth sports and fosterage. In this respect, the elite ice hockey clubs are situated in a legal culture of two parallel norm systems: the tradition of self-regulation in sport and in civil law (e.g., commercial law). Indeed, the incoherent blend of idealism and commercialism in Swedish elite hockey appears to be fertile ground for hazardous (sports) management and indebtedness. This mix of 'uncertainty' and 'immaturity' has given rise to various financial trickeries and negligence, which have subsequently developed into legal matters. Consequently, the legal system appears to have become a playground for Swedish ice hockey. This article reflects on the reasons and the rationale in this frictional development by focusing on a legal case that comes under the Business Reorganisation Act. The analysis reveals support for a 'soft' juridification process in Swedish ice hockey in order to handle the charging tension of the two parallel norm systems.

Keywords: entrepreneurship, public limited company (plc.), non-profit-organisation, bankruptcy, business reorganisation, juridification.

\section{Introduction}

Swedish ice hockey, and particularly SHL, the premier league, is claimed to be the most commercially developed Swedish sport in terms of financial turnovers ${ }^{1}$ and commercial magnetism. Yet, a crucial number of Swedish ice hockey clubs seem to have problems paying their debts. In some cases the clubs have gone into bankruptcy or have been forced to apply for business reorganisation. Although financial shortfalls occur globally, this article dresses the financial problems of Swedish hockey clubs in legal regalia, as principally symptoms of organisational, commercial and legal ambiguities in Swedish ice hockey. In our view, these problems may mainly be understood in light of the tension between the traditional values of the Swedish sports movement (as a non-profit organisation) and the increasing commercialisation of Swedish sport in general, ${ }^{2}$ and in ice hockey in particular. ${ }^{3}$ The problem is that this tension produces 'developmental vacancies' (Cf. below).

The absence of a profound commercial and professional organisation in Swedish sport can principally be explained by a fairly joint interest and an implicit consensus of the sports movement, the market and the political system. ${ }^{4}$ In fact, neither the politicians nor the overall market have had any serious intentions of abandoning the general idea of the Swedish sports movement. The common fear is that an increasing number of commercial mechanisms would

Cf. Backman, I skuggan av NHL, 3.

2 Carlsson and Lindfelt, 'Legal and moral pluralism...'.

3 Backman, I skuggan av NHL.

4 Norberg, Idrottens väg till folkhemmet; Andersson and Carlsson, 'A diagnosis of the commercial immaturity of Swedish club football'. 
run counter to such lauded values as voluntarism, idealism and democracy. Notwithstanding the focus on idealism and voluntarism, Swedish sport depends on the injection of capital from the state as well as the market (e.g., sponsoring). However this capital - i.e., this soft relation to the market - is not related to any developed business strategy and is spent according to the principle of utility-maximization, ${ }^{5}$ which means that the finances are subordinating the clubs' ambitions of achieving sporting results. ${ }^{6}$

However, and regardless of this portrayal of 'commercial immaturity', several individuals - regularly described as patrons, Maecenas or entrepreneurs - have engaged themselves in Swedish elite ice hockey, in order to support a harder market rationality. ${ }^{7}$ For instance, their efforts have resulted in the development of different (sports) plcs (public limited companies), as an alternative to the general association form. However, a serious complication of their tactics has been the ' $51-49 \%$-barrier' for 'sports plcs', which means that a sports plc, in essence, must be majority-owned by a non-profit club, due to an ideological mixture of democracy, fostering and public health. ${ }^{8}$ There is little doubt that the possible abolition of the '51-49-rule' is a serious problem that divides the Swedish sports community. But the collisions between amateurism and commercialism, voluntarism and professionalism, and youth sport and elite sport become apparent and problematic in nonprofit-organisations with commercial ambitions, i.e. the elite ice hockey clubs. ${ }^{9}$

At the same time, this 'uncertain normative foundation' is fertile ground for experiment, innovations and entrepreneurship. In some cases these 'innovative' commercial and managerial experiments may not comply with the relevant laws, due to their ambiguity or 'criminal touch'. At the same time, these cases also direct our attention to a more general trend, attributable to the commercialisation and professionalisation processes; namely, the juridification of sport, ${ }^{10}$ which seems to be a process both internal and external. ${ }^{11}$ Generally, 'the juridification of sport' is regarded with suspicion. There has been a tendency for the sports community to regard the legal system as an inappropriate method with which to govern its cultural heritage and self-managerial structure, because relations, values, patterns and actions in sport are supposed to be hard to reconstruct in accordance with legal terms. ${ }^{12}$ But, sport has undergone a crucial professionalisation and commercialisation process, which has also transformed, to a certain extent, the 'play elements' into more serious business - into rationalisation and into an (entertainment) industry. In the wake of this 'process of seriosity', the law has become a natural element in sport, ${ }^{13}$ despite the latter's self-regulation and normative autonomy image. ${ }^{14}$ Prospectively, the law's intrusion into and influence on sport will test the values of the latter - and, imaginably, also the rationality of the former. ${ }^{15}$

5 Cf. Storm, 'Winners and losers in Danish football'.

6 Cf. Solberg and Haugen, 'European club football...'.

7 Cf. Andersson and Carlsson, 'A diagnosis...'; Andersson, et. al., 'Sweden: the development of club football on the periphery of Europe'; Backman, I skuggan av NHL.

8 Andersson and Carlsson, 'A diagnosis...'.

9 On the contrary, the elite football clubs' representatives support the '51-49\%-barrier', because they essentially are frightened by the commercial drive and the opportunities in the culture of ice hockey, and their constructions of entertaining and amusing 'Hockey Temples'.

10 Gardiner, et al, Sports Law, 66-70 ; Greenfield and Osborn, 'The legal colonization of cricket'; Carlsson, Idrottens rättskultur.

11 Foster, 'The juridification of sport'; Carlsson, 'Insolvency and the domestic juridification...'.

12 Cf. Foster, 'Juridification of Sport'.

13 McArdle, From Boot Money to Bosman; Greenfield and Osborn, Regulating Football; Anderson, Modern Sport Law.

14 Carlsson, Idrottens rättskultur.

15 Carlsson, 'Re(con)fusion of law and sport...'. 
The following essay intends to discuss the problems and the reasons for normative uncertainty, commercial immaturity and hazardous management in Swedish ice hockey. This discussion and analysis are then related to the development of elite ice hockey in Sweden, in the wake of the ideology of the Swedish sports movement and the influence of the NHL (National Hockey League). Furthermore, the indebtedness among the Swedish ice hockey clubs becomes an important target. Consequently, the context of commercial immaturity and entrepreneurship is highlighted. In addition, the increasing juridification of sport becomes accentuated in light of the tensions and immaturity as well as (ingenious) innovations. In this respect, the illuminating case of Leksands IF (LIF), and its legal exposure by the Company Reorganisation Act (1996:764), works as a beneficial and demonstrative subject in this context of cultural heritage, normative uncertainty, hazardous management, entrepreneurship and commercial immaturity. At the end, the 'uncertain normative foundation' in Swedish ice hockey is discussed vis-à-vis the NHL; ${ }^{16}$ an organisation based on more solid and fixed commercial and legal structures. The departure in the article might seem to be broad and 'holistic'. However, this is not the ambition. The main focus is, purely, the tension between two different normative structures with different rationalities and values, which is the fertile soil of the financial and organisatorical problems in Swedish hockey. In this respect, we have designed the article in light of this tension and dialectics, rather than systematically organising the argumentation in different categories and themes.

The aim of the portrayals, and the diagnosis of Swedish elite ice hockey, is neither to advocate nor to principally disregard the Swedish sport model, which is founded in the traditional idea of the Scandinavian sport movement and non-profit organisations/professionalism. In addition, the article will not favour the American model of franchises and Major Leagues or even put forward the European sport logic, with promotion and relegation, as the most promising model of sport. The article has, thereby, the desire to avoid the 'trap' of normativity as well as the character of instrumentalism, which commonly seems to influence sport studies. ${ }^{17}$ Thus, the basic aim is to describe, to diagnose and to understand the status and conditions of the current management in Swedish elite ice hockey, due to its position of being situated in the tension - the dialectics - of two parallel norm systems: one (e.g., commercial law) guiding business and the commercialisation process and the other a norm system stimulated by the tradition and the association forms, that support self-regulation, as well as the values and ideal as youth sport, fostering and health.

Notwithstanding the implicit use of comparative reasonings, the ambition is not to present a comprehensive comparative analysis of Swedish and Canadian/American hockey. On the contrary, these materials and this reasoning are primarily used to describe the origin of certain developmental process in Swedish ice hockey and the present commercial 'skylines' and ambition in Swedish elite hockey. This portrayal should be understood in relation to the traditional culture in Swedish sport movement, as a crucial component in the tension of two parallel norm systems.

\section{Background: the development of Swedish ice hockey}

16 We do not, reasonably, relate our reflection of the external American/Canadian influences on Swedish hockey, and its commercialization process, to national leagues such as CHL/USHL. No doubt, the horizon and the practices of the commercialisation process of SHL are in fact inspired by, and an imitation of, the brand of "The NHL". SHL's tradition of supporting the general European relegation system in team sports should also be grasped in this light. Cf. Carlsson and Hedenborg, 'The Position and Relevance of Sport Studies'. 
The development of Swedish ice hockey is presented from two directions. In the first part the ideological background is illuminated as it lays the foundation of the past as well as the current organisation of Swedish sport in general; an order to which elite ice hockey has had to adapt to. ${ }^{18}$ In the second part the focus is on the commercialisation process and the impact of NHL. This commercialisation process, despite being immature, has brought about a soft juridification process, both in relation to domestic regulations and external legal influences. The domestic approach is highlighted by the implementation of the elite license, which also turns the focus on hazardous (sports) management.

\section{Ideological horizon}

A distinct Swedish' model [Folkhemmet] emerged after World War II, in the wake of the Social Democratic Party's consensus-oriented welfare politics. This model has also shaped the organisation of Swedish sport; e.g., the Swedish sports model with several significant characteristics: First, the model is constructed as a non-profit, non-governmental movement, with the Swedish Sports Confederation [Riksidrottsförbundet, RF] at the top of this pyramidal model. ${ }^{19}$ The Confederation consists of 70 sports associations/sports whereof the Swedish Ice Hockey Association (SIHA) is the fourth largest. ${ }^{20}$ Importantly to stress, the Swedish Sports Confederations meets every second year and, during that meeting, decides the direction of Swedish sport in a democratic procedure, customarily supporting the non-profit organisational. $^{21}$

Although potent on the market and in the media, SIHA is only one of 70 associations when it comes to elections and policy declarations in the Confederation. Another characteristic is the emphasis on fosterage, health promotion and youth sport as well as grassroots sport. A third characteristic is the fact that voluntary sports get a wide-range of public support distributed among all kinds of clubs according to the numbers of their youths and related activities. ${ }^{22}$ Furthermore, the model is linked, like most European sport, to the principle of promotion and relegation, which supports the value of 'sporting uncertainty', but at the same time seems to cause economic risks and hazards. In addition, Swedish elite sport is founded on the principle of utility-maximization, which means that the sports results are given priority over monetary profits. Potential profits are - and must be - reinvested in sport and not levied by an owner.

Consequently, it is these characteristics and principles that have affected the climate, the ideology and the normative structure which, in turn, have steered the development of Swedish ice hockey in one, but essential, respect since its inception at the beginning of the twentieth century, ice hockey in Sweden has become organised in non-profit organisations, in line with

18 Interestingly, particularly from a developmental and normative perspective, the Swedish Football Association was initially governing ice hockey. The SIHA was established in 1922, at a meeting in the Swedish Football Associations facilities in Stockholm. The Swedish Football Association's pragmatic attitudes to the amateur regulations have been reflected the SIHA (Cf. Stark. Folkhemmet på is, 203 and 222).

19 In the Swedish Sports Confederation there are approximately 20,000 clubs and roughly 3 million individuals.

20 This system, the Sport Confederation and the sports associations (such as SIHA) govern all sport in Sweden. As a comparison, Hockey Canada or USA Hockey rules only youth and amateur hockey.

21 For instance, SIHA's current proposition to abandon the 51-49-barrier in order to initiate stronger market logic has been outvoted during recent meetings.

22 The close link between the ideological origin of sport and public support is also revealed by the tax legislation, which gives non-profit sports clubs tax reductions that sport plc.'s do not have. Cf. Income Tax Act (1999:1229), chapter 7. 
the Swedish sports model. Today the SIHA has about 650 organisations and around 85,000 players and referees. The Swedish Hockey League (SHL), formed in 1975/76, is Sweden's highest hockey league and consists of 12 clubs that had a turnover of approximately 1.3 billion SEK in 2012. The clubs in SHL receive the bulk of the spectator, TV-contract and sponsor revenues. The estimated total value for a one year deal is approximately 350 million SEK (approximately 37 million euro), and every club in the SHL receives 27 million SEK a year. ${ }^{23}$ The second division [Hockeyallsvenskan] consists of 14 clubs, with an estimated total turnover of 400-500 million SEK in 2012. Hockeyallsvenskan's TV-contract is supposed to give the individual clubs 2.3 million SEK a year, which is a tenth of what a club in SHL gets. ${ }^{24}$ This financial gap clearly puts considerable pressure on the clubs that face relegation, precisely as it attracts the clubs in the division below.

By tradition Swedish ice hockey is based on promotion and relegation, which means that only sporting performance determines which clubs are granted entry into the SHL. ${ }^{25}$ Certainly, the system of promotion and relegation, and the sports logic, produce a vicious circle of pressure on the individual clubs. Exclusion from the SHL places clubs in a dire financial situation. From this perspective, the organisation of Swedish ice hockey implicitly supports an atmosphere where 'the winner takes it all'. As a result, the hockey clubs involved in this 'cruel pseudo-business' appear to overspend in order to obtain sporting success, without any financial "suspenders".

\section{The 'Americanisation' and the commercialisation process}

The NHL, its commercial atmosphere and the entertainment of the hockey events have attracted the SHL/SIHA in different ways. The 'American way' has influenced the development of Swedish' hockey ${ }^{26}$ through its character of being an entertainment, an event, as distinguished from its style of playing (the Swedish style of playing is more Russian or European). But then again the 'Americanisation process' has had a huge impact on the society in general, which means that American impulses have started to make inroads into genuine local and national traditions. ${ }^{27}$ The concept of 'Americanisation' captures 'a centre and periphery perspective', in which the USA, through its economic and political power, has exported its culture - 'the American way', or the 'American Dream' - to the rest of the world. ${ }^{28}$ Consumption and consumption patterns are copied, more or less, from Planet Hollywood, McDonald, Dallas Cowboys, Chicago Bulls, the Big Apple, shopping malls etc. In the world of ice hockey, this process can be described by the hegemonic position the NHL

23 Ejderhov, 'Hård kamp om TV-rättigheterna'; Bengtsson, 'Dif vill skriva eget TV-avtal'.

24 Bengtsson, 'Dif vill skriva eget TV-avtal'.

25 In order to gain access to SHL the two last placed teams in that league play against the four best teams from Hockeyallsvenskan in a home and away qualification series. The first two teams in that qualification league are promoted to the SHL.

However, it has in general been the image of 'Canadian Hockey' that has flourished in Sweden, in relation to the vision of the NHL. Yet, even Canadian Hockey is permeated by the Americanisation process, and is actually an excellent representative of these cultural values and normative horizon. The American 'gravities' have, in this respect, entered the Canadian national sport. For instance, NHL, as well as the commissioner, is deeply embedded in the United States, despite a centre in Toronto, with the Hall of Fames (Cf. Kidd and Macfarlane, The Death of Hockey; Gruneau and Whitson, Hockey Night in Canada). Alm, Americanitis, 37-38.

Ibid. 
has attained globally in relation to other hockey leagues. ${ }^{29}$ The draft-system in the NHL is an indication of this power ${ }^{30}$ - which causes a considerable migration of talented Swedish ice hockey players ${ }^{31}$ — that is regulated in a special transfer agreement between NHL and SHL/SIHA. ${ }^{32}$

Complementary to this power, the cultural impact of the NHL is significant. We can find, for instance, values, labels, ideas, pictures and symbols with clear American/Canadian origins: Leksand Stars, Frölunda Indians (in Gothenburg), MIF Redhawks and Bofors Bobcats. Other cultural influences are modern multi-arenas with restaurants and conference packages, cheerleaders, offensive tackle, and different game and price ceremonies, all introduced in order to produce an event, an entertainment beyond the 'pure' game, all of which are not particularly 'Swedish'. This commercial development is actually rare in other Swedish sports. Still, all impulses from the NHL have not been incorporated unchanged, but have been adapted to the local conditions. Although the influence from the NHL is substantial, the design of this Americanisation process is not related to external power. It is more connected to the domestic attempts and desires to commercialise Swedish ice hockey along the lines of the NHL. ${ }^{33}$

This 'commercialisation' process in Swedish ice hockey started seriously during the 1970 s, even if commercial advertising had been allowed as early as $1959 .{ }^{34}$ By the 1970 s it had become increasingly clear that the Swedish National Team could not compete with the Soviet Union (CCCP), and to some extent Czechoslovakia, in the international arena. The only way to make Swedish hockey a 'dynamo' internationally was to make the players fully professional and to expand the cooperation with the NHL. ${ }^{35}$ The most noticeable result was

29 Perhaps KHL, the novel Russian league, might challenge the NHL's supremacy. But, regardless of financial potential, the league is being more or less developed to mirror the normative and cultural hegemony of NHL.

30 In order to balance the league and to create an unpredictable league/product, the annual draft allows the team that finishes last in a major league to pick first and the best team to pick last, or 'the worst to pick first', even if there is a draft lottery.

31 An important rationale in Swedish hockey is the players' desire to play in the NHL, and significant players like Börje Salming, Anders Hedberg, Nicklas Lidström, Mats Sundin, Peter Forsberg, Henrik Lundqvist and the Sundin Brothers have left Sweden for successful NHL careers. In some respects, this migration has affected the SHL's ability to attract an audience and to gain status and prestige in the League. Still, this migration has not hurt the SHL in a similar manner as the migration of talented young Swedish football players (aged 16-18) leaving for European football academies. This migration has damaged Swedish club football and has situated the Swedish league on the periphery of European football (Cf, Andersson and Carlsson, 'A diagnosis of the commercial immaturity'; Andersson, Backman and Carlsson, 'The Development of Swedish Men's Professional Club Football in the Periphery of European Football').

32 The reason for the transfer agreement is to maintain good relations between the NHL and SHL/SIHA. Nevertheless, the NHL dictates the conditions in the transfer agreement, so a move to North America is compensated marginally. In the most recent seven-year transfer agreement, signed in 2013, Swedish ice hockey was to be compensated with USD 225,000 for the ten first players that leave and with USD 325,000 thereafter. Every Swedish club receives similar compensation, which is divided by the total number of players who have moved to the NHL during the year. (Idrottens affärer, '2,1 miljoner kronor per spelare ...'). Backman, I skuggan av NHL, 10-11.

34 Östman, Från byalagen till Leksand Stars, 71.

35 In some respect, the Swedish National Team (Tre Kronor) has been rather successful in the Olympics and in the World Championship. And, evidently, nationalism and success in international competitions, as in all sport, are important factors, which have also affected the 
that the SHL was formed and its matches were played for the first time in the 1975/1976 season, in order to strengthen the quality and generate a more stringent, efficient and commercial Swedish ice hockey league. The logic and rationale were that the implementation of the SHL would substantially increase revenues, and generate greater attractiveness and entertainment by means of better standards among the players. ${ }^{36}$

After the SHL was established, the league became the major and most vital advocate for the commercial development of Swedish sport. Initially, when the SHL started, the league was labelled 'Elitserien om Volvo Cup', named after the main sponsor, Volvo. This was, and still is, ${ }^{37}$ an aberrant step in the history of Swedish sport. Up to then, no sports league had sold, or even been interested in selling, its name or 'brand' to any commercial business interests.

No doubt, the growing economic elements in SHL benefitted the players, who became professional or semi-professional in the mid-1970s. ${ }^{38}$ Besides the traditional and regular revenues from attendances and bingo, television and sponsoring became important factors in this gradual commercialisation during the $1980-90 \mathrm{~s} .{ }^{39}$ Beginning in the year 2000, various entrepreneurs and Maecenas have entered the scene, focusing more intensively on the commercial and entertainment aspects of ice hockey. ${ }^{40}$ Their involvement has also contributed to the development of 'sport plcs' as an alternative association form. This, in some sense, market-adapted transformation of Swedish sport was approved in 1999, especially after pressure from the SIHA/SHL. ${ }^{41}$ As a result, it has since been possible to allow the construction of a 'sport plc', but in the domain of a non-profit sport club (Cf. above). Obviously, the mixture of the non-profit movement and commercial ambitions creates tensions as well as normative and commercial uncertainties and ambiguities. Therefore, it is not surprising that, for instance, the Swedish Market Court [Marknadsdomstolen] and the Swedish Competition Authority [Konkurrensverket, KKV] has recently been forced to intervene in different cases. ${ }^{42}$ As an example, KKV had to intrude when two of the clubs in the SHL, Modo Hockey and Frölunda HC, refused to comply with the SHL's decision to

image of Swedish' hockey and the league. For instance, the triumphs have evidently, in a historical perspective, supported the value of the Swedish' sport model. SHL, 'Serieutredningens förslag till nytt seriesystem'.

However, there are sports clubs in Sweden that have allowed their name to be used by a business company; e.g. LdB FC (women's football), Team-Boro (men's hockey), Kopparbergs FF (women's football) and Sallén Basket (women's basket).

Östman, Från byalagen till Leksand Stars, 133-7; Stark, Svensk ishockey 75 år. Del I, 60; Del II, 17; Stark, Folkhemmet på is; Backman, I skuggan av NHL.

Fahlén, Structures Beyond the Framework of the Rink.

Andersson and Carlsson, 'A diagnosis...'.

Backman, I skuggan av NHL, 50-3.

The SMC reacted, in 2012, to a unique case concerning the organization of Swedish sports. The question in the case was if the solidarity rule in the Swedish Automobile Sports Federations competition rules, based on the Swedish Sports Confederations statutes, violates the Competition Act (2008:579). The Swedish Market Court ruled on 20 December 2012 that the Swedish Automobile Sports Federation is not allowed to have a total ban on functionaries or drivers in competitions that are not sanctioned by the federation (Cf. The Swedish Market Court, 2012:16, Dnr. A 5/11 (2012-12-20). This ruling is most interesting in that the Swedish Market Court decision puts competition law over the constitutionally protected right of associations. In addition sport clubs must pay attention to competition law, and non-profit movements' benefits as tax relief can be contested. Especially noticeable is that the Swedish Market Court did not take into account the traditional organization of Swedish sports. The Swedish Market Court decision also runs contrary to the established sports politics held by the Swedish Government and Parliament. 
exclude NHL-players on short-term contracts during the NHL-lockout in 2012. Legal predictability is neither clear nor evident. ${ }^{43}$ In this case, the SHL's 'monopolistic' decision was overruled by KKV, which ruled that it was inadmissible under current antitrust laws. This judgement was based on the fact that the clubs were to be regarded as a 'business' and that the SHL was acting as a cartel. But the legal proceedings continued when the SHL appealed to the Swedish Market Court, which in turn overruled KKV's decision. The final judgement was that the rules of the short-term contracts might, in some cases, match the antitrust laws. In this case, the court ruled that the use of short-term contracts was legitimate. In addition, the court held, interestingly, that a certain imbalance could occur during the season, corresponding to the level of skills and effectiveness of the clubs. ${ }^{44}$

Surely, when legal decisions contradict each other, the implicit message is that the legal predictability in Swedish elite sport is a complex issue. And so it is! The legal outcomes of these cases have occasionally confronted and challenged the traditional norms and forms of organisation of sport, which are upheld by the Swedish Sport Confederation as well as the Swedish Parliament. Some legal decisions seem to contradict each other mutually, which is a sign of 'normative uncertainty'. In this context, Swedish sport, in particular the SIHA/SHL due to commercial ambitions, finds itself in a milieu of normative uncertainty, which generates and reproduces commercial immaturity. This has accentuated the thesis of the juridification of ice hockey, when it comes to both domestic regulations and external (legal) governance.

An internal juridification: the elite licence

As a result of the increasing commercialization, which seems to be occurring in a context of 'normative uncertainty', several elite ice hockey clubs in Sweden have suffered, and are still suffering, from overspending. In Sweden's top two ice hockey leagues, there are twenty-six clubs (twelve clubs in the SHL and fourteen clubs in Hockeyallsvenskan) in total, of which six are sport plc's (three in each league). Four of the sport plc's have had huge economic problems, and several of the non-profit clubs have been affected by similar issues. Faced with these challenges, the SHL has been forced, by common agreement, to strengthen the domestic regulations. One step in this direction was the realisation in 2001 of an interest group, the Swedish Hockey League, plc [Svenska Hockeyligan AB]. A similar group was also established in 2004 for the clubs in the second division, AHF Hockeyallsvenskan, plc. In order to develop a healthier and more sober commercialisation process, and thereby eliminate overspending, the SIHA/SHL established a mutual cooperation agreement: the 'Regulations for the SHL's league board', anno 2004. In this way the 'Elite License' was introduced, inter alia. ${ }^{45}$ Instead of a system of (hard) salary caps, as in the NHL, the SHL has chosen a model of sound finance for its individual clubs, which should be presented and evaluated both in its annually reported economic records and in its balance sheets. Since then, sporting success has become insufficient for qualification (being one of the ten!) for the SHL. In addition, the clubs must now be able to meet certain specified demands regarding, for instance, financial stability, organisational progress, venue requirements and youth activities. Moreover, the League Board has been established as a regulatory board, which independently determines if a

43 The present legal dispute could be compared with how Swedish hockey dealt with the NHLlockouts in 1994 and 2004. During the 1994 NHL-lockout, two NHL players were allowed at every SHL-club; there where no restrictions during the 2004 NHL-lockout. (Cf. Ros, 'NHLinvasion i elitserien 2004').

44 The Swedish Competition Authority, 2012-09-20, Dnr 501/2012; The Swedish Market Court, 2012-12-03, Case A 2/12, appendix no. 48.

45 In comparison, the Elite License in Swedish football was implemented in 1999, Cf. Carlsson, 'Insolvency...'. 
club, in a perilous situation, is able to meet the demands. To receive a 'license to SHL' the club cannot be insolvent or have a negative equity in the annual reports of two consecutive financial years. Besides, the club must have a firm organisation and an arena of acceptable quality when it comes to operations, seats, restaurants and comfort. Otherwise, the club runs the risk of being regulated, despite sporting success. The SIHA adopted largely similar regulations for the second division [Hockeyallsvenskan] in 2006. The League Board, as the supervisory authority, has had the task of monitoring, for instance, Leksands IF's financial status (Cf. below).

\section{Trends of hazardous (sport) management}

Sustainable finances are a criterion according to the SIHA/SHL's internal regulations (e.g. elite licence) as well as the external regulations, e.g. the Accounting Act (1999:1078) and Annual Reports Act (1995:1554). Despite this governance, several ice hockey clubs have been damaged by their own hazardous (sports) management. In the worst scenario, clubs have gone into bankruptcy: Team Boro in 1994, IK Vita Hästen in 1996, Örebro IK in 1999, Västerås IK in 2000, in Halmstad Hammers 2005, and Hammarby Hockey in 2008, all of them, however, playing in lower divisions. At the same time, clubs in higher divisions, such as Malmö Redhawks plc in 2009 as well as in 2012, Björklöven plc in 2010, Frölunda HC in 2011, Timrå IK in 2013, Mora IK and Leksands IF in 2013 (Cf. below), have all been at the edge of bankruptcy.

One of the problems that have created managerial ambiguities is the involvement of too eager and passionate Maecenas, characterised by impatience, a short temper, and the ambition to take a vital role in the club owing to their supply of considerable capital, despite lacking the 'cultural capital of hockey pedigrees'. For instance, Malmö IF/Malmö Redhawks plc is an interesting case. ${ }^{46}$ Usually playing in the "backyards" of Swedish hockey, the club triumphed in 1991/92 and 1993/94 with a 'Dream Team', due to the infusion of a considerable amount of money by Percy Nilsson, a 'self-made' building developer. Malmö Redhawks received, thereby, the financial muscle to play a significant role in Swedish ice hockey. However, since being relegated from the SHL in 2004/05 and 2006/07 the club has fallen into managerial collapse, twice at the edge of bankruptcy. Although Nilsson has paid the bills and even established a novel fashionable multi-arena á la mode for the club, his engagement has gradually declined. His contention is that it is impossible for SHL to progress as long as business rationality has to be mixed with a non-profit-mentally. He argues that there is too much idealism even in activities that are essentially commercial. But, according to him, 'sport is just about business and this is what we have to accept' ${ }^{47} \mathrm{He}$ has taken a radical stance, in a Swedish sports context, which has made him more or less unserious and impossible. Besides, in 2007, his expectation was that 'we (Swedish ice hockey, our remark) will face more external (foreign) owners in Swedish ice hockey, i.e, international companies who will promote themselves on a big market'. ${ }^{48}$

Expectedly, the Swedish Tax Authority has scrutinized Redhawk's management and business concept. In addition, the club and Nilsson have been targeted in judicial proceedings. Optimistically, the club and Nilsson were innovatively seeking unfamiliar alternatives, some of which were hazardously motivated and subjected to legal intervention. During 2012, in the wake of Nilsson's gradual departure from the club, Redhawk's board started to corporate with Hugo Stenbeck, an external financier and the son of a media-tycoon. An admirer of the US sports model, Stenbeck was followed by a bad reputation from an earlier unsuccessful

46 In 1996/97 Malmö IF changed the name to a more NHL-like label, Malmö Redhawks.

47 Nilsson, 'Det är för mycket idrott i sport'.

48 Ibid. Yet, notwithstanding local magnitude, Swedish ice hockey is not like Indian cricket! 
'entrepreneurial' involvement in Linköping HC, at that time a quite new club in the SHL. However, Stenbeck promised Redhawks a three-year deal totalling 60 million SEK. During the first season (2012/2013) this 'extravagant' cooperation placed Redhawks as no. 7 in Hockeyallsvenskan, the second division. Even this venture ran into trouble and led to lawsuits, ${ }^{49}$ as well as an appeal to the Company Reorganisation Act (1996:764). Redhawks has since started a new and more constrained concept without Stenbeck, in order to prevent being 'mocked' in Swedish hockey.

At the end of 2012, the financial and legal ambiguities in Swedish ice hockey peaked with the financial difficulties of Leksand IF/Stars, a classical club, regarded as a 'cultural carrier' in Swedish sports history (Cf. below).

In addition to the individual malpractices in the respective hockey clubs, these financial troubles, overspending and experiments are also symptoms of a more serious wide-ranging problem. However, before we analyse that problem more extensively, we turn to the puzzle of Leksands IF (LIF), which serves as a blueprint of the general trends of problems, questionable actions, and disputes in Swedish ice hockey clubs. Still, the case of LIF is, according to 'media logic', more striking and quite extraordinary due to the tensions between the law, business, individuals' determinations, traditions, brand/image, and cultural capital.

\section{The case: Leksands IF and the Company Reorganisation Act}

No doubt, Leksands IF Ice Hockey (LIF) is a suitable case - and ideal typical milieu -in order to illustrate a complex mix of traditions, culture, regional loyalty, political support, strong national trademark, ${ }^{50}$ hazardous (sports) management, commercial immaturity, entrepreneurship, normative uncertainty, legal responses, and the question of internal (domestic) and external 'juridification'.

To start: LIF plc is supposed to have debts, discovered in 2012, of up to 152 million SEK, which is an enormous amount of money in the context of Swedish sport. In this respect, LIF has lived beyond its means during the last four years, and 'the situation is very severe', according to LIF's CEO Anders Doverskog. ${ }^{51}$ The main sponsor, Ejendals, states sorrowfully, 'I have financially protected the club in earlier days, but not now. We are currently talking about a significant sum of money. My financial support has been crystal clear. And without this funding the club would have fallen into bankruptcy long ago...' (Cf. below) ${ }^{52}$ Furthermore, critics in the national sports media, such as Janne Bengtsson, argue that: 'LIF is a small Swedish "darling" in the hockey family that can, more or less innocently, be poorly managed, year after year, despite the fact that all involved in ice hockey are aware that it is in deep financial trouble. And by financial-technical strokes, the club is still able to continue on a boulevard of sloppiness'. ${ }^{53}$ In addition, the local political opposition in Leksand has reacted strongly: '-Somewhere there must be a limit. It can't be possible to mismanage an activity in such an irresponsible manner, and at the same time repeatedly be saved by capital from the municipality', says Eric Böwes, representing the local Green Party. 'The club's "track record" is not particularly convincing, ${ }^{54}$ Let us examine the club's financial and cultural chronicles!

\section{The History and Culture of LIF}

49 Several board members have sued Stenbeck, the CEO and the sports manager for malpractice and deception.

$50 \quad$ Cf. Aldskougius, Leksand, Leksand, Leksand!, 21.

51 Nilsson, 'Så hamnade Leksand i den akuta miljonkrisen'.

52 Idrottens affärer, 'Leksand i desperat behov av 25 miljoner'.

53 Bengtsson, 'Ekonomisk dopning måste stoppas'.

54 Ibid. 
LIF was formed in 1919 as a non-profit organisation. The ice hockey section, founded in 1937, is a traditional, popular ice hockey club from one of the Northern provinces (Dalarna), with large supporter groups scattered throughout the whole country. The municipality (Leksand) has approximately only 6,000 inhabitants. The support of the club is provided by 9,000 members, ${ }^{55}$ and the official supporter club, Leksand's Superstars, has around 2,000 members. That there exists special support for LIF was especially revealed when LIF was relegated from the SHL in 2001. The supporters initiated a 'Dalariot' [Dalaupproret], with 'The Return' [Återtåget] as their motto. The public and the politicians in Leksand municipality have also backed LIF through the years. ${ }^{56}$ One illuminating example is that LIF was able to purchase the old stadium from the municipality for a pittance. ${ }^{57}$

From a historical perspective, LIF is a fairly successful ice hockey club, particularly on the ice and among the supporters. The club has had fifteen seasons in the SHL and four national championships. However, from 2006 onwards the club has played in Hockeyallsvenskan (the second division), despite several (unsuccessful) attempts in the 'qualification league'. ${ }^{58}$ During this period the notion of 'The New Return' to SHL has shaped the mentality and the board's action plans (Cf. below).

The club has also been characterised by different innovative and novel forms of associations. In 1989, a decision to dissolve the club was taken at the Annual General Meeting, because of the increasing financial imbalance between the hockey club and the other sections during the 1980s. As a result, the two new organisations were formed: LIF Sports Alliance, ${ }^{59}$ and LIF Ice Hockey (a non-profit organisation). In the wake of this separation, the commercial aspects have increased. LIF Ice Hockey has recently constructed two different plcs: 1) LIF Ice Hockey plc has been, engaged in the sporting elite operations since 2011, and 2) LIF Real estate plc owns and operates the Tegera Arena.

LIF and Djurgårdens IF, from Stockholm, were the first to experiment with plcs, as well as the motivation to enter the stock market in the 1990s. Thus, the representatives of LIF had early visions of a possible 'market adaption'. Still, the traditions and the culture of LIF, at least until 1990, were thorough and systematic and guided by the norm of not overspending to acquire new players. ${ }^{60}$ But the economical responsibility and seriosity that characterised LIF before the 'roaring 80s' were lost somewhere along the way (Cf. below).

The increased financial unbalance was one reason for the market representatives of LIF to unbundle the business in 2011. The aim was to achieve financial balance through this

55 One of Scandinavia's largest clubs, AIK from Solna/Stockholm, has approximately 16,000 members.

56 Cf. Idrottens Affärer, 'Politikerna räddar Leksand, men...'.

57 Ejderhov, 'Dokument Leksand - en kamp för överlevnad'.

58 Cf. note 25.

59 A 'Sports Alliance' is an umbrella organisation where former sports sections in a club have established their own legal status. When a sports club transforms to a sport alliance, the new club in the alliance keeps the name and logotype of the original club. A sports alliance is usually established when the financial differences between sports/sections in a club are too big or when it is not effective to run a club with many different sports.

60 Cf. Östman, Från byalagen till Leksand Stars. In this context (i.e., the problem of acquiring new players), it might be instructive to mention the Post-Bosman situation in European sport. Since the Bosman ruling (C-415/93), players are free agents when their contracts expire, and the ruling has strongly contributed to the escalation of salaries, especially in ice hockey and in football (Cf. Halgreen, European Sports Law, 51-4, 167-8, 189-201). In sum, players can be secured by a club's own talent development, by absorbing local players, by signing free agents as Bosman, or by trading with other teams (but a trade requires the players approval). Draft procedures like in the NHL are not allowed in the SHL. 
action plan. ${ }^{61}$ Yet, this ambition was not fulfilled because LIF was dramatically threatened by a 'financial meltdown' and a 'juridical assay'. ${ }^{62}$

The process to reorganise LIF in light of their commercial hazards

The debts that were discovered in 2012 pushed the club into an exceptionally fragile situation. LIF was facing bankruptcy, and not only would the financial situation be affected, but LIF's sporting position would also be negatively affected for an extensive period. A scary scenario was that LIF would become forced to play in the 'backyard' in the foreseeable future, because the SIHA internal regulations state that a club or sport plc that is insolvent or bankrupt is not allowed to play in the SHL or in Hockeyallsvenskan. ${ }^{63}$ The club would be relegated. Besides, the players would be able to end their contracts and leave the club as 'free' players, as a consequence of the bankruptcy. ${ }^{64}$ Accordingly, a bankruptcy would be devastating for the club, both in the short term and long term. In this light, the representatives of LIF became rather exposed, and realised that the club was in need of external assistance, or, to be frank, a 'lifebuoy'.

The LIF board decided to apply for business reorganisation, after consulting legal expertise in insolvency laws. This led to a certain focus on the Company Reorganisation Act (1996:764) as a possible 'lifebuoy'. ${ }^{65}$ This legislation does not exclude any business enterprise, because the term 'business' is to be interpreted broadly and include all organisations engaged in business activity of a financial nature. This means that even nonprofit sports clubs and sports plcs have the right to apply for business reorganisation as long as they have the prerequisites for successful business reorganisation. ${ }^{66}$ Yet, regarding LIF's general attitude, this threat of legal intervention and its impact on the club seems not to have distressed the board and their management of the club. Instead of preparing for a 'steel bath', the attitude was that the sporting performance was not going to be affected. ${ }^{67}$ Still, the budget for players is going to be cut for the season $2013 / 14,{ }^{68}$ but the sports manager, Tommy Salo, claims that this financial drop will not impair the current season. 'We are going to play the season. I will wait to speculate until April (at the start of the next season), and if we are compelled to make changes in the team we will probably make something good come out of these efforts. At the moment, we have no influence on what will happen outside the rink. We have to adapt to the circumstances'. ${ }^{69}$

And so, when Mora district court granted LIF's application for business reorganisation on December 12, 2012, ${ }^{70}$ the immediate crisis was avoided. The court appointed a bankruptcy

61 Idrottens affärer, 'Bolagisering ska rädda Leksands IF'; 'Nu jagar Leksand nya aktieägare'; 'Leksand fick in 8,8 miljoner kr'.

62 Cf. Ejderhov, 'Har Leksand kringgått reglerna?'

63 SIHA, Competition rules 2012/2013, chapter 6.

64 Ibid; Cf. Employment Protection Act (1982:80).

65 Company Reorganisation Act (1996:764), chapter 1, $1 \S$ and chapter 2, $1 \S$; Cf. Ministry of Justice, Lag om företagsrekonstruktion, 171; Welamson and Mellqvist, 'Konkurs och annan insolvensrätt', 290.

66 Company Reorganisation Act (1996:764), chapter 1, $1 \S$ and chapter 2, $1 \S$; Cf. Ministry of Justice, Lag om företagsrekonstruktion, 171; Welamson and Mellqvist, 'Konkurs och annan insolvensrätt', 290.

67 Helmersson, 'Det sportsliga påverkas inte'.

68 Eriksson, 'Kostnadskostymen har varit för elitserien'.

69 Ibid.

70 Mora District Court, Case no. Ä:1612-12; Cf. Company Reorganisation Act (1996:764), chapter 2, 7 § and Chapter 2, 17-19 §§; Jofer, 'Emthén en av landets erfarnaste rekonstruktörer'. 
trustee with the delicate task of sorting out the assets and liabilities, as well as investigating what circumstances had prompted the debts. In this respect, the prevalent self-image of LIF, that is, the club, by tradition, did not overspend on players' salaries, was quickly detected as an illusion, and indefensible from a Swedish perspective. The ambitious determination to (re)enter SHL, Swedish ice hockey's exclusive club, had pushed LIF to its financial limits. For example, the monthly salaries, for the season 2012/13, were between 12,500 and 130,000 SEK, of which three players had monthly salaries that exceeded 100,000 SEK. ${ }^{71}$ (The average salary in Sweden 2012 was 29,800 SEK per month.) Yet, these salaries are not the most 'ostentatious' in LIF's history. When Pelle Prestberg, a talented Swedish sniper, was recruited in 2008, he received a monthly salary of 220,000 SEK, despite the fact that LIF was not playing in the SHL, ${ }^{72}$ and that few players in Swedish ice hockey had similar incentives. When the Stanley Cup-winning goalkeeper Ed Belfour - as the face of 'impression management' - was signed in 2007 at the age of 42, he was given a monthly tax-free salary corresponding to 400,000 SEK. In spite of extraordinary salaries, and over 100 players representing the club between 2006 and 2010, the corresponding sporting results were lacking. ${ }^{73}$ Thus, the management appears to have been fairly shortsighted, with rather considerable expenditures.

In addition, the new multi-arena was a heavy burden. Currently, the real estate liabilities of LIF amount to 107.8 million SEK. In some way, LIF's ambition to develop a modern fashionable multi-arena might be thought remarkable and impulsive considering the small municipality. However, LIF was, as many small municipalities in Sweden were, mentally affected by the general 'arena-boom' ${ }^{74}$ Repair and renovation of the old arena would be more cost-efficient. In order to build the new arena, at a cost of 129 million SEK, LIF was forced to take a bank loan of 85 million SEK. However, the municipality contributed 15 million SEK, as an investment grant, in addition to 70 million SEK that was invested in various municipal sports facilities, including a parking area outside the arena. Besides, different sponsors, with Ejendals in the forefront, ${ }^{75}$ had to put in several millions into the building. The new stadium, Ejendals Arena, named after the main sponsor, was opened in $2005 .^{76}$

Evidently, the question of public support of new and modern multi-arenas in minor municipalities has been an appealing target for the media, due to the dubious usages of tax

71 Jofer, 'Så mycket får spelarna i LIF i lön'.

72 This was crucial to LIF's economy. The club did not receive similar revenues to the clubs in the SHL. Still, the budget for LIF's players harmonized with some of the impressive clubs in SHL. According to SICO (Swedish ice hockey players' central organisation), the trade union, the average salary in the SHL is 75,000-90,000 SEK per month, but star players can earn three- to four-times this amount (Cf. SICO, 'Ekonomi bland lag och spelare i svensk hockey').

73 Ros, Lockades med jakt'; Nilsson, 'Så hamnade Leksand i den akuta miljonkrisen'.

74 Cf. Book and Carlsson, Idrott och city-marketing.

75 Ejendals, a family owned business and a work-wear manufacturer, has supported LIF annually since 1949, through targeted sponsorship. During 2002-2010 Ejendals put in over 50 million SEK in LIF. Per Olof Ejendal has rarely missed a match in Leksand. It was Ejendals father, Valfrid, who initiated the sponsoring of LIF by purchasing a lifetime ticket, in 1956, for $600 \mathrm{SEK}$, at that time, a way to pay for a rink with artificially frozen ice. Cf. Jofer, 'Lunch med storsponsorn...'.

76 An interesting detail, in the margin of this essay, is that Ejendals will be able to use the tax law in order to reduce its costs for purchasing the name right and the sponsoring of LIF, due to the fact that businesses are allowed to deduct revenue and sponsoring. Cf. Income Tax Act (1999:1229), chapter 16. 
incomes. ${ }^{77}$ LIF/Leksand has recently become a vital media target, although this kind of public support is by no means unique to the city of Leksand.

The concept behind the new arena was, for sure, new forms of revenues (i.e., restaurants, 'networking' and conferences). However, the new multi-arena has not only given the LIF new opportunities for revenues, but has unfortunately also served as a perilous undertaking for the club. The arena has not yet been able to cover its costs. The annual deficit has been nearby 20 million SEK, even if the multi-arena has housed different popular entertainments, such as the Swedish qualification for the Eurovision Song Contest. Years of commercial deficit have accumulated, where the financial unbalance has finally threatened to sink the club. The multi-arena appears to have been too pretentious and too expensive for a club and a municipality in a town like Leksand. ${ }^{78}$ Several critical commentators have questioned how it has been possible for LIF to acquire an elite license in view of their documented overspending and debt. In this matter, LIF, notwithstanding its cultural legacy, appears to be a special case in Swedish ice hockey, since it has been kept floating by a history of audit technical moves, pen strokes, and obsequious turns among the local politicians. ${ }^{79}$

The decision

After the debts were discovered and evaluated, the process to get an agreement on debt reduction (composition) was launched. ${ }^{80}$ In addition, and during the evaluation, LIF received a governmental wage guarantee. ${ }^{81}$ The purpose of the Wage Guarantee Act (1992:497) is to give employees financial support when an employer is bankrupt or undergoes business reorganisation. But the Act and the public financial support have not been planned with hockey players in mind. This legal loophole, according to opponents, has created a sporting advantage for LIF. ${ }^{82}$

Of course, the main reason to offer a debt reduction ( $75 \%$ in all), through the Company Reorganisation Act (Act (1996:764)), was to preserve LIF as well as to secure some compensation for the defenceless creditors ${ }^{83}$ When LIF's business reorganisation was finally settled in Mora district court on February 14, 2013, the total sum available for 150 creditors was approximately 57 million SEK. In addition to the municipality, the creditors were the Swedish tax authority and major sponsors such as Ejendals, Leksand's Savings Bank and the ice-hockey competitors Djurgården Hockey AB (plc) and Mora IK. The creditor that was affected hardest was Leksand's Savings Bank, which received 25 percentage of its 33.5 million SEK claim. Of the creditors, the banks supported business reorganisation, while the Swedish tax authority, which had a less sympathetic standpoint, rejected the settlement. Still, the Tax Authority could not prevent the business reorganisation because its share as a creditor

77 E.g. Swedish Television ('Uppdrag Granskning') presented, in June 3, 2013, the following findings: In the case of LIF, the municipality board of Leksand has supported LIF by means of a 'loan' of 8 million SEK to improve the multi-arena and a yearly rental (2.5 million SEK) to 2035 for public ice time. This was done during the club's hardest financial troubles, at the same time as they chose to close a school, due to the lack of finances. Cf, SVT, 'Uppdrag Granskning synar Leksands kommun'.

78 Idrottens affärer, 'Leksand i desperat behov av 25 miljoner'.

79 Bengtsson, 'Ekonomisk dopning måste stoppas'.

80 Welamson and Mellqvist. Konkurs och annan insolvensrätt, 272; Cf. Bankruptcy Act, chapter 12, and Company Reorganisation Act, chapter 3.

81 Jofer, 'Så mycket får spelarna i LIF i lön'; Granlund, 'Leksand: “Vi har ingenting att skämmas för"'.

82 Other clubs that have received similar governmental wage guarantees during their recovery in 2012/2013 are MIF Redhawks and Timrå IK.

83 Carlér, Ansökan om företagsrekonstruktion. 
was legally too 'small' ( $8.5 \%$ of the total amount $).{ }^{84}$ In the end, LIF received assistance, and, as a result of the district court's decision, the club prospered financially. For instance, and as a potential effect of the governmental wage guarantee, LIF did not lose any players as free agents when the contracts were fulfilled. Further, due to there being no regulations in the licence system that governed this kind of governmental debt reduction (composition), the Swedish ice hockey's Elite License did not become an obstacle.

This successful outcome in court, ${ }^{85}$ was accompanied by success in the hockey rink, and LIF can look forward to playing in the SHL in 2013/2014, a league that they have so eagerly aspired to after being relegated in 2005/2006. Opponents might argue that the return is due to financial doping and basically a triumph in the legal proceedings; as such it is more than a sporting success, and in that respect unfair and morally wrong in several aspects.

\section{Analysis}

The following, concluding, part analyses the previously presented hazardous (sports) management in Swedish ice hockey, with particular focus on: 1) the dialectics between transition and traditions, 2) the ambiguous form of associations (normative uncertainty), 3) the unintended support of entrepreneurship and innovations, and 4) the arguments of utilitymaximization and profit-maximization. This discussion will end up in 5) a reflection on the value of an increasing juridification of Swedish ice hockey.

First, sport is changing, and is now a part of the entertainment industry. The traditional ideological values, such as democracy, integration, fostering and health, are still held in high esteem and are integral parts of the Swedish sports model. Ice hockey in Sweden, due to its commercial prospects and its close connection to the development of the NHL, has found it harder to adapt to the Swedish sport model than other sports organisations. At the same time, the problems that have harmed several hockey clubs in Sweden are simultaneously a) proof of malpractice and hazardous (sports) management among the clubs, and b) an implicit indication that the Swedish sports model, with an emphasis on non-profit organisations, has had difficulty coping with a serious commercialisation process. This ideological resistance causes an 'immature' commercialisation process, which works more as a tail of the general body of non-profit sports organisations. Consequently, and regardless of the history of financial recklessness in Swedish hockey, it is difficult to regard a club such as LIF as a 'crass business', especially in view of its profound image of a lot of 'culture custodians' originating in the Swedish sport model. Besides, a municipality (like Leksand), which sponsors the local hockey team with advantageous loans or rents, attracts suspicion. Compared to most other countries, a Maecenas, such as Ejendals, is not recognised or highly regarded in Sweden. ${ }^{86}$ This makes the question of capital difficult, per definition. In brief, commercialisation in nonprofit movements creates tensions.

The ideology of idealism and non-profit is, secondly, manifested in the organisation of sports. Hence, non-profit organisations are favoured in Swedish sport for several reasons, notwithstanding the recent development of 'sport plcs'. To begin with, the principle of democracy is a central reason for the support of non-profit organisations as the principal forms of association. Surely, this ideological horizon in Swedish sport must be emphasised as

84 Swedish Courts, 'Rekonstruktionen av Leksands IF'; Jofer, 'LIF segrade i rätten'; Ödén, 'Facit av Leksands uppgörelse'. The rules of creditor majority are described in Company Reorganisation Act (1996:764), chapter 3. Cf. Carler, Ansökan om företagsrekonstruktion... Mora District court, Case no. Ä:1612-12; Carler, Ackordsförslag och rekonstruktörsberättelse.

86 Swedish capitalists, influenced by the Wallenberg Family and their virtue, shall work, but not be visible. Cf. Andersson and Carlsson, 'Diagnosis...'. 
a critical issue. Essentially, it is a political issue, and the reason, in scientific terms, is that the empirical question in every single case ${ }^{87}$ is whether a non-profit-organisation generates democracy or not. Truly, official ideology and affirmative images will not produce democracy per se. When it, secondly, comes to financial benefits, a non-profit organisation receives valuable tax reliefs as well as public funding, i.e. arenas, and direct financial contributions to clubs that run youth sport. These categories of public assistance will not be tangible for a plc. On the other hand, a plc will have the possibility of attaining investments and external capital that is not possible for a non-profit sports organisation today. Still, the public support, and its 'sanctuary', has attracted most sports clubs in Sweden. ${ }^{88}$ Apart from this funding, an alternative has been the development of 'sports plcs', in order to a) meet the demands from the SIHA, and b) more or less deal with the increasing commercialisation in general. However, the construction of the Swedish sport plcs has not incorporated comprehensive market logic, due to the 51-49\%-barrier (Cf. above). ${ }^{89}$ Thus, the new forms of association have indirectly and unintentionally created organisational ambiguity and more or less 'dualistic organisations', as indicated by the organisational developments and their indefinite linkages in LIF (e.g. LIF Sports Alliance, LIF Ice Hockey, LIF Ice Hockey plc and LIF Real estate plc). The operation of clubs in Swedish ice hockey is, consequently, shaped by a mixture of the non-profit movement, commercial ambitions and novel (ambiguous) forms of 'semi-plcs', which causes a normative uncertainty, ad hoc governance and commercial immaturity.

Thirdly, the dualistic and confusing organisation of Swedish hockey - the mixture of sport plcs and the non-profit ethics - can be presented as a normative and commercial laboratory for innovations and entrepreneurship. This condition should, of course, be understood rightly, and thought of as an unintentional 'support' of entrepreneurship and innovations. LIF's signing of Ed Belfour, as well as their deal with Peter Nordström, paying him for individual games, ${ }^{90}$ instead of a salary, belong to these alternatives and 'tests'. Another example, from LIF, is an external financier stepping in during LIF's business reorganisation, and paying for the recruitment of a new goalkeeper before success in the qualification league 2012/2013, thereby giving LIF a competitive advantage.

But more importantly, several clubs, like Leksand, have differentiated and constructed plcs (Real estate plc) for their arenas, restaurants and shops. In this regard, the development of multi-arenas is characterised by entrepreneurship as well as by hazardous management. Historically, it has been public funding that has enabled the construction of stadiums. Nonetheless, through entrepreneurial involvement and private founding, in addition to public support, it has been possible to build new modern and fashionable multi-arenas, in a manner beyond the horizon of public funding. The mushrooming of multi-arenas is also a symptom of the Americanisation of Swedish elite ice hockey and the transformation of Swedish hockey into a 'consumer society' - a consumption culture. The play progresses towards an 'event' entertainment - which attracts and stimulates entrepreneurs and Maecenas to find new revenues. At the same time it is hard to ignore the financial gamble when new stadiums are built, regardless of financier. In general, interest and amortisation are to be paid.

87 Cf. Coakley, Sports in Society.

88 The Annual Meeting of the Sport Confederation in 2013 returned a majority for the barrier, despite SIHA's ambition to abandon the principle.

89 The Swedish rules for sport plcs differ from other Nordic countries, where there are no majority-rules.

90 This was a novel approach to 'entrepreneurship' in Swedish ice hockey. Curiously, we can find players in early Canadian hockey, such as Fred 'Cyclone' Taylor, who were effectively mercenaries, playing played for a number of teams, sometimes on a game-by-game basis (Cf., Gruneau and Whitson, Hockey Night in Canada, 88). 
Consequently, new multi-arenas, which are supposed to create opportunities for novel revenues, might become a serious and injurious problem for the private financers and creditors; e.g., Leksands Savings Bank (LSB). In this vein, it is not hard to understand LSB's pragmatic attitude towards the reorganisation proceedings. An expensive arena, in a tiny municipality, in a rural area, and without a tradition of ice hockey, generates virtually nonexistent revenues.

Although certain clubs have also been able to rent arenas to the public (for school or leisure activity), LIF's deal with the municipality of Leksand is extraordinary, and must fairly be considered as 'camouflaged sponsoring'. Besides, there are clubs that have been able to relate, to different degrees, to an (external) investment group that owns the player's right and most of the income of a potential trade. This seemingly pragmatic and progressive situation might be seen as positive, despite the milieu of normative uncertainty. By building the argument on socio-legal studies, situations of normative uncertainty can produce frustration and anomie, not to mention a playground for innovations and novel solutions regarding the forms of organisation. But if these 'innovations' and 'tests' lack direction and predictability because of a vague normative structure, there is an imminent risk that the innovations will develop hazardously. At the end of the road, the entrepreneurs and the innovations will face... the Law. It is important to stress that several attempts made in Swedish ice hockey by entrepreneurs or the club's board are to be regarded as a) 'innovations', b) having a hint of offense or malpractice, and c) a sign of normative uncertainty. They should naturally be regarded as accountable for the 'transgressions', but perhaps 'morally excused' in light of a normative uncertainty in the dualistic organisation of Swedish hockey. This is, evidently, an alternative way to handle and analyse the discourse and the moral blame. ${ }^{91}$

The 'dualistic concept' is, apparently, a dilemma, and fertile ground for different problems and pioneering experiments, Notwithstanding a certain level of domestic commercialisation process, this 'dual model' does not have the advantages of the NHL, when it comes to commerce. The normative uncertainty in Swedish ice hockey seems to produce hazardous (sports) management and commercial immaturity. A fourth dilemma to accentuate is the crucial normative and organisational differences between the NHL and

SHL/Hockeyallsvenskan, which essentially exist despite the cultural analogy. As mentioned, the SHL's commercial vision and culture are shaped by the NHL, and consequently by the 'Americanisation process'. The mentality and the brands are closely connected to the image of the NHL. Still, the legal and organisational structures are fundamentally based on the Swedish sports model, as well as the European sports model.

The NHL is largely based on profit-maximization, whereas the SHL is based on utilitymaximization, as most sports in Europe are. In the financial culture of utility-maximization the clubs - and the leagues - employ the entire finances and the investment (the 'utilities') in order to obtain the best possible sporting results. The clubs put forward sporting success as the fundamental value, which, consequently, directs the club's managerial rationality. Closely connected to this principle is the 'paradigm of relegation', which is an 'open system' with the

91 No doubt the morality can be discussed, and there are certainly those who believe that the hockey clubs' business is unethical. But it is still a legal issue. Besides, an Elite License regulation stating that composition and business reorganization, and not only insolvency, should result in relegation, would have most likely avoided the collision between ice hockey's logic, morality and the law, as for instance in the Leksand case. Furthermore, the question of the government wage guarantee, as in the case of LIF, as an indirect support to achieve sporting results is not a question the legislature took into account when the Act was developed. This blunder or disregard could, however, be corrected through the elite license by stating that clubs that need salary guarantees would be relegated. But no action has been taken by the SHL/SIHA. 
opportunity or the risk of going up and down in the league system. As an implicit result of the mix of utility-maximization and relegation, the SHL and Hockeyallsvenskan appear to have developed a hazardous (sports) management among those clubs that struggle to remain in the SHL and those that eagerly desire to move from Hockeyallsvenskan to SHL, at any price. On the other hand, the principle of profit-maximization means that economic profit is the main driving force. Consequently, the club owners in the NHL (i.e., Anschutz Entertainment Group, Jeremy Jacobs (Boston Bruins), Wirtz Corporation, Comcast Spectacor (a Philadelphia-based American sports and entertainment company), Lemieux Group LP and Maple Leaf Sports and Entertainment aspire to achieve a generous financial outcome. Sporting success is not unimportant, but almost subordinated to profits. The NHL, with franchisees, drafts and salary caps, is closely linked to the principle of profit-maximization. ${ }^{92}$ In order to produce a maximum of profit, the horizon is an unpredictable league. Thus, in order to secure the club's investment and the risks, the league is closed, which means that, unlike the SHL/Allsvenskan, the (financial) fear of relegation per se is removed.

Consequently, the commercial playground is safer. Besides, the normative structure and the legislation (i.e. the right of a franchise) are firm and predictable, and produce an industrious milieu for the league, as long as there are consumers. In sum, the SIHA, SHL and Hockeyallsvenskan have to work in an uncertain normative structure with ad hoc solutions and commercial immaturity. More commercially mature sports and leagues have generally stricter internal regulations and legal predictability, and are also increasingly shaped by an external juridification process. Evidently, the Swedish model could, strategically, be compared with the Finnish Liiga; ${ }^{93}$ a league that has more substantially and consistently followed the route of the NHL, and the 'Americanisation process' and its impact on normative, organisational and commercial structures. ${ }^{94}$

As the case of LIF clearly indicates, the judicial intervention changes the conditions, even though sport traditionally has been regarded as an autonomous sphere to which the law does not belong. But the juridification of sport will increase, ${ }^{95}$ for good reasons. A solution for Swedish hockey would be supplementary 'laws' that could generate a more stable normative structure, in addition to the enactment of self-regulated league(s).

Interestingly, in the 80s and 90s, numerous studies on the sociology of law advocated self-regulation, as an alternative legal strategy to purposive and regulatory Welfare Laws, ${ }^{96}$ and the 'deluding' and 'colonising' juridification process. ${ }^{97}$ On the contrary, sport has historically - in Sweden as in many other countries - mainly developed as a self-regulated semi-autonomous system, ${ }^{98}$ but with a current need of 'soft' juridification in addition to the

92 Cf. Vamplew, Pay Up and Play the Game, 77-79; Halgreen, European Sports Law.

93 Cf. Backman, I skuggan av NHL, 61-66.

94 Ibid. After the experiences of bankruptcies in the 1990s the Finnish Liiga has acted quite radically, compared to the SHL/SIHA. In order to increase a commercial predictability, and to eliminate the hazards of relegation, the league has been closed for a decade. And since 2013 the league has established a licensing procedure; i.e. clubs that want access to the Finnish Liiga have to apply for this right, like franchisers in the NHL. Besides, the Finnish Liiga is not framed by the 'Swedish 51-49-rule', which supposes raising the revenues from the market. Consequently, the mixture of non-profit and commercial activity has been eliminated, through allowing full market logic. The obtained benefits are an enhanced basis for commercialisation, a reduction of budget deficits and an increased legal predictability, i.e. clear tax rules. Cf. ibid.

Cf. Foster, 'The juridification of sport'; Gardiner, et al, Sports Law, 66-70.

Cf. Rottleuthner, 'The limits of law...'; Teubner, 'After legal instrumentalism...'.

Habermas, 'Law as a medium and law as an institution'.

Luhmann, 'The self-reproduction of law and its limits'. 
increasing commercialisation and professionalisation processes. ${ }^{99}$ In this respect, the legal system might start and initiate learning processes, ${ }^{100}$ which could improve the normative structures in commercial sport (e.g. SHL and Hockeyallsvenskan). As presented in this article, there are several external Swedish laws that might facilitate a profound internal governance/juridification of the SHL and Hockeyallsvenskan. ${ }^{101}$

\section{Conclusion}

Importantly, the analysis and our diagnosis avoid a strong conclusion. In this respect, the reasoning's legacy is a diagnosis, related to the symptoms (see below). Still, the analysis will not end up in a possible cure. Instead we advocate, by this diagnosis, a certain 'self-medication' (i.e., discourses in SHL/SIHA). 102

Consequently, we have argued that the major problems ('symptoms') in Swedish elite ice hockey - including hazardous management, commercial immaturity, normative uncertainty, and legal disputes - could basically be understood in light of the tension of two parallel norm systems, focusing either on business (commercial law) or on non-profitorganisation (sport's association laws). We have argued that this tension makes it difficult to develop a profound commercialisation of Swedish ice hockey at the same time as market approaches risk diluting the ideals in the traditional Swedish sport movement. In this respect, we call for a substantial legal discourse, a minor juridification process. This would develop a more certain normative structure, guiding the future of Swedish elite ice hockey, which could then incorporate pluralistic visions of the Swedish sport model, the European sport logic, and the horizon of the commercial NHL-system.

This discourse could be guided by the following rationale and reasoning: Sport should be uncertain, but the normative structures ought to be fixed and predictable. The domestic regulations and the normative structure, as well as external laws, should work as predictable sources that create unpredictability in sport and sports results, thereby accepting hazards in the rink, but favouring solid and mutual rules in the boardrooms.

It is recurrently - and reasonably - argued that the greatness of sport stems from its ability to produce a 'sweet tension of uncertainty of outcome'. ${ }^{103}$ Yet, in regard to 'European Utility Maximization' this 'uncertainty' appears questionable when it comes to the top leagues. But the battle to avoid relegation is nevertheless uncertain and hazardous. As a result, the leagues are fairly 'unbalanced', causing hazardous (sports) management and precarious infusion of capital, in order to avoid a 'sporting downgrade'. By contrast, in the vision of 'American Profit Maximization', the league is more balanced and, at the same time, uncertain due to the mutual interest of producing fertile ground for increasing profits for all parties (e.g.

99 Carlsson, '(Re)confusion...'; Carlsson and Lindfelt, 'Legal and moral pluralism...'.

100 Eder, 'Collective learning and social evolution'.

101 I.e. the Accounting Act (1999:1078), the Annual Reports Act (1995:1554), the Bankruptcy Act (1987:672), the Company Reorganisation Act (1996:764), the Employment Protection Act (1982:80), the Income Tax Act (1999:1229) and the Wage Guarantee Act (1992:497).

102 The current action (and the discourse) is alterations in the system of relegation and qualification in order to make SHL implicitly closed. It will, as a result, become materially harder for a team in Allsvenskan to reach the SHL.

103 Loland, Fair Play, 149. 
clubs and their owners), ${ }^{104}$ which also produces the value of an uncertain league, however closed it may be. Still, NHL has not always been an effective and profitable business. ${ }^{105}$

In spite of the influences and attractions of the NHL, it is rather hard to imagine Swedish sport with a complete Major League-model á la the NHL, with franchises, drafts and a closed league, despite the Americanisation process and the NHL inroads into Swedish hockey culture. The European sports model and the legacy of the Swedish sports movement are part and parcel of a persevering heritage.

Of course, these two institutions will not automatically diminish the demand for general discourses dealing with the progress of commercially sober ice hockey in Sweden, with adequate room for 'entrepreneurship' - beyond the attitudes of hazardous (sports) management. The reasoning in this article supports a soft juridification (domestic as well as external). Accordingly, these legal discourses - and learning processes - could stimulate and work as a dynamo for the growth of a firm and functional association form, normative predictability, and commercial maturity in the SHL and Hockeyallsvenskan, thereby confronting ice hockey with the law... (before KHL fiercely hit the league(s)).

\section{References}

Aldskougius, H. Leksand, Leksand, Leksand! En studie av ishockeyns betydelse för en bygd. [Leksand, Leksand, Leksand! a study of ice hockey's impact on a community]. Hedermora, Gidlund, 1993.

Alm, M. Americanitis: Amerika som sjukdom eller läkemedel: svenska berättelser om USA åren 1900-1930. [Americanitis: America as a disease or medicine: Swedish stories about USA 1900-1930]. Diss. Lund University, 2002.

Anderson, J. Modern Sport Law. Oxford: Hart Publisher, 2012.

Andersson, T. and Carlsson, B. 'A diagnosis of the commercial immaturity of Swedish club football'. Soccer and Society 12, no. 6 (2011): 754-773.

Andersson, T., Backman, J. and Carlsson, B. 'Sweden: the development of club football on the periphery of Europe', 187-203. In The Transformation of European Football: Towards the Europeanisation of the National Game. Eds. A. Niemann, B. Garciá and W. Grant. Manchester University Press, 2010.

Backman, J. I skuggan av NHL: En organisationsstudie av svensk och finsk elitishockey. [In the shade of NHL: An organization study of Swedish and Finnish elite ice hockey] Licentiatavhandling, Institutionen för Kost- och idrottsvetenskap, Gothenburg University, 2012.

Bengtsson, J. 'Ekonomisk dopning måste stoppas'. [Financial doping must be stopped]. Svenska Dagbladet. December 13, 2012. http://www.svd.se/sport/ekonomiskdopning-maste-stoppas_7753142.svd (Accessed, September 24, 2013).

104 Cf. Wong, Lords of the Rinks, 91, 98-99, 121-122, 125, 143-148, 151; Lavoie, 'Ice hockey', 597.

105 Some NHL clubs do not make a profit. Several NHL clubs have an extremely low number of attendances in new markets, and several teams (e.g., Pittsburgh, Ottawa, and Buffalo) have gone through bankruptcy procedures. Other clubs have been under surveillance by their banks and must provide supplementary security. Another issue is that 'tax breaks' provide club owners possibilities to reduce profits. Despite these financial shortcomings, a belief exists that the NHL has been a successful business throughout its history (Cf, Lavoie, 'Ice hockey', 544-546; compare Kidd and Macfarlane, The Death of Hockey, 121). 
Bengtsson, J. 'Dif vill skriva eget TV-avtal'. [Dif wants to sign their own TV-deal]. Svenska Dagbladet. January 31, 2013. http://www.svd.se/sport/dif-vill-skriva-eget-tvavtal 7326453.svd (Accessed, September 13, 2013).

Berglund, H. Ed. Pucken: en bok om svensk ishockey. [The Puck: a Book on Swedish Ice Hockey]. Stockholm: Strömbergs idrottsböcker, 1972.

Book, K. and B. Carlsson, Idrott och city-marketing. [Sport and City-Marketing]. Malmö: idrottsforum förlag, 2008.

Carler, Law Firm. Ansökan om företagsrekonstruktion för Leksands IF Ishockey AB och Leksands IF Fastighets $A B$ [Application of business reorganisation for Leksands IF Ice Hockey plc and Leksands IF Real estate plc]. Mora District court, December 19, 2012. http://www.carler.se/files/documents/leksands-ifishockey-ansokan-om-foretagsrekonstruktion-2012-12-12.pdf.pdf (Accessed, 2013-04-22)

Carler, Law Firm. Ackordsförslag och rekonstruktörsberättelse LIF Fastighets AB. [Business reorganisation proposal and trustee report LIF Real estate plc]. Mora District court, December 19, 2012. http://www.carler.se/files/documents/Underrattelserekonstruktorsberattelse-mm-LIF-Fastighets-AB.pdf (Accessed, 2013-04-21).

Carler, Law Firm. Ackordsförslag och rekonstruktörsberättelse LIF Ishockey AB (Business reorganisation proposal and trustee report LIF Ice Hockey plc]. Mora District court, December 19, 2012. http://www.carler.se/files/documents/Underrattelserekonstruktorsberattelse-mm-LIF-Ishockey.pdf. (Accessed, 2013-04-21).

Carlsson, B. Idrottens rättskultur. [The Legal Culture in Sport]. Malmö: idrottsforum förlag, 2009.

Carlsson, B. 'Insolvency and the domestic juridification of football in Sweden'. Soccer and Society 10, no. 3/4 (2009): 477-94.

Carlsson, B. 'Re(con)fusion of law and sport in light of "seriousness" and "trivialisation"', Sport in Society 17, no. 9 (2014) 1-17.

Carlsson, B. and S. Hedenborg. 'The Position and Relevance of Sport Studies: an introduction' in Sport in Society 17, no. 9 (2014) 1-9. DOI:

Carlsson, B. and M. Lindfelt. 'Legal and moral pluralism: normative tensions in a Nordic sports model in transition' in Sport in Society 13, no. 4 (2010) 718-33.

Eder, K. 'Collective learning and social evolution', Tidskrift för rättssociologi 1, no. 4 (1983): 337-60.

Ejderhov, T. 'Har Leksand kringgått reglerna?' [Has Leksand circumvented the rules?]. idrottensaffarer.se. January 29, 2013.

http://www.idrottensaffarer.se/affarer/2013/01/har-leksand-kringgatt-reglerna (Accessed, April 16, 2013)

Ejderhov, T. 'Hård kamp om TV-rättigheterna.' [A vicious battle for TV-rights]. idrottensaffarer.se. January, 31, 2013. http://www.idrottensaffarer.se/tvnyheter/2013/01/hard-kamp-om-tv-rattigheterna (Accessed, September 13, 2013).

Ejderhov, T. 'Dokument Leksand - en kamp för överlevnad'. [Documentary Leksand - a struggle to survive]. idrottensaffarer.se, February 16, 2011. http://www.idrottensaffarer.se/affarer/2011/02/dokument-leksand-en-kamp-foroverlevnad (Accessed, September 15, 2013).

Eriksson, A. 'Kostnadskostymen har varit för elitserien' [The costume of outlay has been designed for SHL], Expressen. December 13, 2012.

http://www.expressen.se/sport/hockey/hockeyallsvenskan/kostnadskostymenhar-varit-for-elitserien/ (Accessed, September 20, 2013). 
Fahlén, J. Structures Beyond the Framework of the Rink - On Organization in Swedish Ice Hockey. Diss. Umeå University, 2006.

Foster, K. 'The juridification of sport', 155-182. In Readings in Law and Popular Culture. Ed. S. Greenfield and G. Osborn. London: Routledge, 2006.

Gardiner, S., A. Felix, M. James, R. Welch and J. O'Leary. Sports Law. London: Cavendish, 1998.

Granlund, P-Å. 'Leksand: "Vi har ingenting att skämmas för"”. [Leksand: We have nothing to be ashemed of]. Dalarnas Tidning, September, 18, 2012.

http://www.dt.se/sport/hockeyfeber/1.5407068-lif-ordforande-vi-har-inget-attskammas-for- (Accessed, September 5, 2013).

Greenfield, S. and G. Osborn. Regulating Football: Commodification and Consumption. London: Polity Press, 2001.

Greenfield, S. and G. Osborn. 'The legal colonization of cricket', Soundings, Issue 13, 1999.

Gruneau, R. and D. Whitson. Hockey Night in Canada: Sport, Identities and Cultural Politics. Toronto: Garamond Press, 1993.

Habermas, J. 'Law as a medium and law as an institution'. In Dilemmas of Law in the Welfare State, 203-20. Ed. G. Teubner. Berlin: Walter de Gruyter, 1986.

Halgreen, L. European Sports Law - A Comparative Analysis of the European and American Models of Sport. Diss. Copenhagen University, 2004.

Helmersson, A. 'Det sportsliga påverkas inte' [The sporting is unaffected]. Dala-Demokraten, December, 13, 2012.

Idrottens affärer. 'Bolagisering ska rädda Leksands IF'. [Corporatisation is going to save Leksands IF]. idrottensaffarer.se. April 12, 2011.

http://www.idrottensaffarer.se/affarer/2011/04/bolagisering-ska-radda-leksandsif (Accessed, September, 23, 2013).

Idrottens affärer. 'Nu jagar Leksand nya aktieägare'. [Leksand is searching for new stockholders]. idrottensaffarer.se. September 4, 2011.

http://www.idrottensaffarer.se/affarer/2011/09/nu-jagar-leksand-nya-aktieagare (Accessed, September, 23, 2013).

Idrottens affärer. 'Leksand fick in 8,8 miljoner kr'. [Leksand obtained 8, 8 million SEK]. idrottensaffarer.se. October 5, 2011.

http://www.idrottensaffarer.se/affarer/2011/10/leksand-fick-in-88-miljoner-kr (Accessed, September, 23, 2013).

Idrottens affärer. 'Leksand i desperat behov av 25 miljoner'. [Leksand is in a desperate need of 25 million SEK]. idrottensaffarer.se. November 10, 2012.

www.idrottensaffrer.se/affarer/2012/10/leksand-i-desperat-behov-av-25miljoner (Accessed, September 15, 2013).

Idrottens affärer, '2,1 miljoner kronor per spelare...' [2.1 millon SEK per player...], idrottensaffare.se. May 9, 2013

http://www.idrottensaffarer.se/transfers/2013/05/21-miljoner-kronor-per-spelare (Accessed, January 15, 2014).

Idrottens affärer. 'Politikerna räddar Leksand, men...'. [Politicians rescues Leksand, but...] idrottensaffarer.se. November 19, 2012

http://www.idrottensaffarer.se/affarer/2012/11/politikerna-raddar-leksand-men (Accessed, April 16, 2013).

Joffer, B. 'Lunch med storsponsorn - sedan gick Åman'. [Lunch with the main sponsor - then Åman had to leave]. Dalarnas Tidningar, September 16, 2010.

http://www.dt.se/sport/hockeyfeber/1.3063281-lunch-med-storsponsorn-sedangick-aman (Accessed, September 17, 2013). 
Joffer, B. 'Så mycket får spelarna i LIF i lön'. [This is the amount of the salaries in LIF]. Dalarnas Tidning, September 19, 2012. http://www.dt.se/sport/1.5405862-samycket-far-spelarna-i-lif-i-lon (Accessed, September 5, 2013).

Joffer, B. 'Emthén en av landets erfarnaste rekonstruktörer'. [Emthén is one of the most experienced bankruptcy trustees]. Dalarnas Tidningar. December 12, 2012. http://www.dt.se/sport/hockeyfeber/1.5387674-emthen-en-av-landetserfarnaste-rekonstruktorer (Accessed, September 5, 2013).

Joffer, B. 'LIF segrade i rätten'. [LIF succeeded in the court], Dalarnas Tidning. February 14, 2013. http://www.dt.se/sport/1.5584324-lif-segrade-i-ratten. (Accessed, April 10, 2013).

Kidd, B. and J. Macfarlane. The Death of Hockey. Toronto: New Press, 1972.

Lavoie, M. 'Ice hockey' In Handbook on the Economics of Sport, 542-551. Ed. W. Andreff and S. Szymanski. Edward Elgar, Cheltenham, 2006.

Leksand city council. Sammanträdesprotokoll. [Meeting Minutes]. Dnr.2011.338 009. Mars 28, 2011. http://www.leksand.se/Documents/Nyheter/2013/LIF\%c3\%a4rendet/Interpellationssvar.pdf (Accessed, April, 18, 2011).

LIF Hockey AB. Inbjudan till teckning av aktier i Leksands IF Ishockey AB. [Invitation to subscribe shares in Leksands IF Ice Hockey plc]. fi.se. September 2, 2011. http://www.fi.se/templates/ProspektFile.aspx?guid=84B5B0AC-FA4C-43A0A9C5-7AE10CBCC280. (Accessed, April 16, 2013).

Luhmann, N. 'The self-reproduction of law and its limits'. In Dilemmas of Law in the Welfare State, 111-27. Ed. G. Teubner. Berlin: Walter de Gruyter, 1986.

McArdle, D. From Boot Money to Bosman: Football, Society and the Law. Oxford: Cavendish Publishing, 2000.

Ministry of Justice, Lag om företagsrekonstruktion. [The Regulation of the Reconstruction of Companies]. Proposition 1995/96:5. Stockholm: Nordstedt, 1995.

Mora District Court, Case no. Ä:1612-12. Aktbilaga 6-7. December 12, 2012.

Nilsson, N. 'Så hamnade Leksand i den akuta miljonkrisen' [The manner in which Leksand ended up in an emergency million crisis]. Expressen. October 11, 2012 www.expressen.se/sport/hockey/hockeyallsvenskan/sa-hamnade-leksand-i-denakuta-miljonkrisen (Accessed, September 16, 2013).

Nilsson, P. 'Det är för mycket idrott i sport', [There is too much PE in sport]. Realtid.se. May $5,2008$. www.realtid.se/ArticlePages/200805/05/20080505084624_Realtid623/2008050 5084624 Realtid623.dbp.asp (Accessed September 17, 20132013-09-17).

Norberg, J. R. Idrottens väg till folkhemmet. Studier i statlig idrottspolitik 1913-1970 [Sports road to the welfare state. Studies in Swedish government policy towards sport 1913-1970]. Stockholm: SISU Idrottsböcker, 2004.

Ros, T. 'Lockades med jakt' [Baited by hunting]. Aftonbladet, August 28, 2007. www.aftonbladet.se/sportbladet/hockey/sverige/allsvenskan/article11219566.ab (Accessed, September 16, 2013).

Ros, T. 'NHL-invasion i elitserien 2004', [NHL-invasion in SHL 2004]. Aftonbladet, November 6, 2003. http://www.aftonbladet.se/sportbladet/article10409916.ab (Accessed, January 13, 2014).

Rosentraub, M. S. Major League Losers: the Real Cost of Sports and Who's Paying for it. New York: Basic Books, 1999.

Rottleuthner, H. 'The limits of law - the myth of a regulatory crisis'. International journal of sociology of law 17 (1989): 273-85.

SICO, Swedish Ice Hockey players central organisation (trade union). 'Ekonomi bland lag och spelare i svensk hockey’ [Economy among clubs and players]. 
http://www.sico.nu/Ekonomiblandlagochspelare.htm (Accessed, January 13, 2014).

SIHA, Swedish Ice Hockey Association. Extra årsmöte den 28 april 1974. Serieutredningens förslag till nytt seriesystem. [Additional annual meeting April 28, 1974. Series Committee's proposal for a new league system]. 1974.

SIHA, Swedish Ice Hockey Associations statutes, chapter 11. Stockholm: SIHA, 2013.

SHL, Swedish Ice Hockey Association. Competition rules 2012/2013, Stockholm, 2012.

SHL, Swedish Hockey League. 'Serieutredningens förslag till nytt seriesystem. [SHL's Proposal for a New League]. Stockholm: SIHA, 1974.

Sloane, P. J. 'The European Model of sport', 299-303. In Handbook on the Economics of Sport. Ed. W. Andreff and S. Szymanski. Edward Elgar, Cheltenham, 2006.

Solberg, H. A. and K. J. Haugen, 'European club football: why enormous revenues are not enough?' Sport in Society 13, no. 2 (2010): 329-343.

Stark, J. Ed. Svensk ishockey 75 år: Historien om svensk ishockey. Del I/II. [Swedish Ice hockey 75 Years: Vol I/II. The History of Swedish Ice Hockey]. Vällingby: Strömberg/Brunnhage, 1997.

Stark, T. Folkhemmet på is: Ishockey, modernisering och nationell identitet $i$ Sverige 19201972. [Folkhemmet on Ice: Ice Hockey, Modernization and National Identity in Sweden 1920-1972). Diss. Växjö: Linnéuniversitet, 2010.

Storm, R. K. 'Winners and losers in Danish football: commercialization and developments in European and Danish first-tier clubs' in Soccer and Society 12, no. 6 (2011): 737-753.

Swedish Companies Registration Office. Emissionsanmälan Leksands IF fastighets AB [Emission notification Leksands IF real estate plc]. February 8, 2005. http://www.leksand.se/Documents/Nyheter/2013/LIF\%c3\%a4rendet/Emissionanma\%cc\%88lan.pdf (Accessed, April 18, 2013).

Swedish Courts [Sveriges Domstolar]. 'Rekonstruktionen av Leksands IF - bolag klar efter tingsrättsbeslut' [Reorganisation of Leksands IF - business finished after district court decision]. domstol.se. Press release. February 14, 2013. http://domstol.se/Om-Sveriges-Domstolar/Pressrum/Nyheter-ochpressmeddelanden/Rekonstruktionen-av-Leksands-IF-bolag-klar-eftertingsrattsbeslut/ (Accessed, April 10, 2013).

Swedish Market Court, 2012:16. Dnr. A 5/11. December 12, 2012.

Swedish Sports Confederations statutes, chapter 11, Stockholm, 2013.

SVT, 'Uppdrag Granskning Synar Leksands Kommun'. [Swedish TV examines Leksand's municipality]. Swedish Television. June 3, 2013.

Http://Www.Svt.Se/Sport/Leksands-If-Betalde-En-Krona-For-Ishallarna. (Accessed, September 19, 2013).

Teubner, G. 'After legal instrumentalism: strategic models of post-regulatory law'. In Dilemmas of Law in the Welfare State, 299-326. Ed. G. Teubner Berlin: Walter de Gruyter, 1986.

Vamplew, W. Pay Up and Play the Game: Professional Sport in Britain 1875-1914. Cambridge University Press, 1988.

Welamson, L. and M. Mellqvist. Konkurs och annan insolvensrätt [Bankruptcy and the Insolvency Laws]. Stockholm: Norstedts Juridik, 2013.

Wong, J. Lords of the Rinks: The Emergence of the National Hockey League 1875-1939. University of Toronto press, 2005.

Ödén, H. 'Facit av Leksands uppgörelse' [The result of Leksands settlement]. idrottensaffarer.se. February 20, 2013. 
http://www.idrottensaffarer.se/kronikor/2013/02/facit-av-leksands-uppgorelse. (Accessed, April 2, 2013).

Östman, L. Från byalagen till Leksand Stars. [From a Village Club to Leksands Stars].

Nacka: Con Scientia Ab, 1996. 